\title{
Accessory Duct of the Submandibular Gland
}

\author{
Prakash B. Billakanti
}

\section{القناة إضافية للغدة تحت الفك السفلي}

$$
\text { بركاش بابو بالاكانتي }
$$

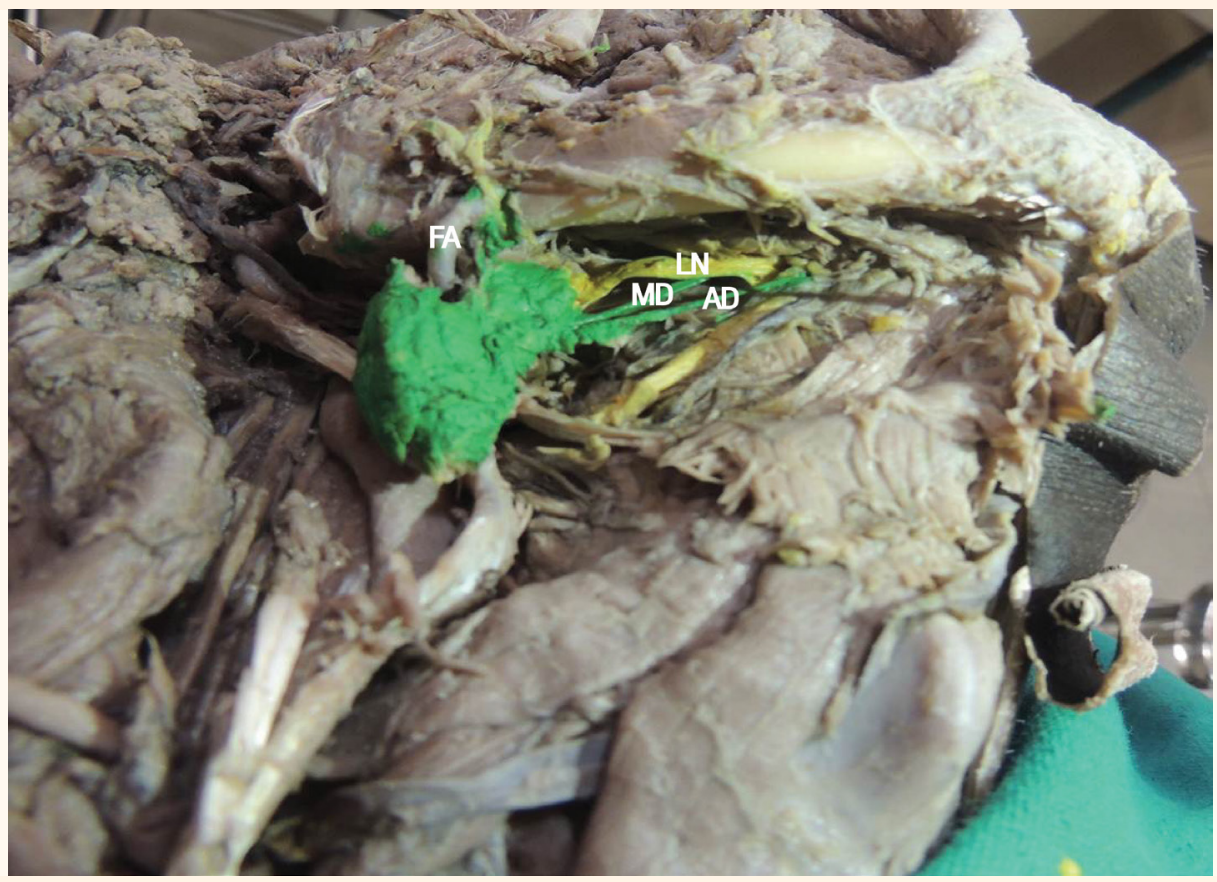

Figure 1: Photograph of the right submandibular gland of an adult male cadaver showing a main submandibular duct with a lower accessory duct arising independently from the gland.

$F A=$ facial artery; $L N=$ lingual nerve; $M D=$ main submandibular duct; $A D=$ accessory submandibular duct .

A ROUTINE DISSECTION WAS PERFORMED ON a 54-year-old adult male cadaver at the Department of Anatomy, Kasturba Medical College, Manipal, Karnataka, India, in 2015. During dissection of the neck, it was noted that the submandibular gland on the right side had an anatomical variation in the form of an extra duct [Figure 1]. No other anomalies were observed. The main duct was larger and superior in position and the accessory duct was slightly narrower and inferior. The two ducts were almost parallel to each other, passing between the hyoglossus and mylohyoid muscles. Only the upper duct had normal anatomical relations to the lingual nerve. Both ducts rose independently from the submandibular gland and opened separately into the floor of the mouth. The main submandibular duct opened at the top of the papilla. The accessory duct adjacent to the main duct produced a slight elevation of mucosa in the floor of the mouth. The submandibular gland on the left side was normal.

\section{Comment}

The submandibular gland is one of the three larger pairs of salivary glands. ${ }^{1}$ It has an excretory duct which emerges from the anterior end of the deeper part of the gland, crosses inwards between the mylohyoid and hyoglossus muscles and opens into the floor of the mouth on the top of the sublingual papilla next to the frenulum of the tongue. ${ }^{1}$ The submandibular 
gland develops during the sixth week of fetal life as an endodermal outgrowth from the floor of the alveologingival groove. ${ }^{2}$ The edges of the floor of the alveologingival groove gradually fuse together to form the submandibular duct; if the duct branches early or invaginates in two places, it may lead in rare cases to the formation of an accessory submandibular gland and duct. ${ }^{3-5}$ Accessory submandibular ducts are usually smaller and run parallel to the main duct. ${ }^{5}$

Only eight cases of bilateral anomalies of the submandibular duct have previously been reported; of these, two were cases of bilateral submandibular duct duplication. ${ }^{4,6}$ Although the larger duct of the submandibular gland is usually anatomically consistent, rare variations can occur. Rose reported a case in which the main duct bifurcated near the gland with one branch opening as usual in the sublingual papilla and the other opening into the oral cavity floor opposite the second molar. ${ }^{7}$ Gaur et al. described a right submandibular gland with three separate ducts which opened independently into the oral cavity. ${ }^{8}$ Manzur-Villalobos et al. reported a cadaver in which an externally located right submandibular duct anastomosed with the parotid duct and led to the buccal mucosa adjacent to the second molar. ${ }^{9}$ In the present case, both the main and accessory ducts opened separately into the floor of the mouth on the right side of the frenulum of the tongue.

Most duplication anomalies are detected incidentally during sialography and are usually not a cause for concern. ${ }^{3,5}$ Sialography is regarded as the diagnostic procedure of choice for the detection of various conditions of the salivary glands, including mass lesions, inflammatory disorders, calculi and penetrating trauma. ${ }^{10,11}$ However, the presence of radiolucent stones or disease in accessory ducts may inadvertently be overlooked. Therefore, information regarding the possibility of additional ducts opening separately into the floor of the mouth is essential for oral surgeons and radiologists. Kuroyanagi et al. observed a duplication of the submandibular duct without any histological abnormalities in duct structure in a 26-year-old woman via sialographic examination. ${ }^{3}$ Using digital sialography and magnetic resonance imaging, Gadodia et al. identified a unilateral submandibular duct duplication with a small duct of $2 \mathrm{~cm}$ in length passing close to the main submandibular duct and draining a small accessory gland. ${ }^{5}$ Awareness of potential variations of the excretory ducts of the salivary glands can aid in the accurate diagnosis and treatment of patients with salivary conditions as well as help surgeons avoid further complications or duct lacerations during oral surgery.

\section{References}

1. Standring S. Grays Anatomy: The anatomical basis of clinical practice, 40th ed. Philadelphia, Pennsylvania, USA: Churchill Livingstone, 2008. Pp. 499-526.

2. Pownell PH, Brown OE, Pransky SM, Manning SC. Congenital abnormalities of the submandibular duct. Int J Pediatr Otorhinolaryngol 1992; 24:161-9. doi: 10.1016/01655876(92)90142-C.

3. Kuroyanagi N, Kinoshita H, Machida J, Suzuki S, Yamada Y. Accessory duct in the submandibular gland. J Oral Maxillofac Surg Med Pathol 2007; 19:110-12. doi: 10.1016/S0915-6992 (07)80027-6.

4. Codjambopoulo P, Ender-Griepekoven I, Broy H. [Bilateral duplication of the submandibular gland and the submandibular duct]. Rofo 1992; 157:185-6. doi: 10.1055/s-20081032994.

5. Gadodia A, Seith A, Neyaz Z, Sharma R, Thakkar A. Magnetic resonance identification of an accessory submandibular duct and gland: An unusual variant. J Laryngol Otol 2007; 121:e18. doi: $10.1017 /$ S0022215107008602.

6. Myerson M, Crelin ES, Smith HW. Bilateral duplication of the submandibular ducts. Arch Otolaryngol 1966; 83:488-90. doi: 10.1001/archotol.1966.00760020490017.

7. Rose BH. Bifurcation of the submaxillary duct. Am J Surg 1932; 17:257-8. doi: 10.1016/S0002-9610(32)90492-9.

8. Gaur U, Choudhry R, Anand C, Choudhry S. Submandibular gland with multiple ducts. Surg Radiol Anat 1994; 16:439-40. doi: 10.1007/BF01627668.

9. Manzur-Villalobos I, Pérez-Bula L, Fang L. Anatomical variation of submandibular gland duct. Scholars J Dent Sci 2016; 3:12-4.

10. Gates GA, Johns ME. Diagnostic radiology. In: Paparella MM, Shumrick DA, Eds. Otolaryngology, 2nd ed. Philadelphia, Pennsylvania, USA: Saunders, 1980. Pp. 1067-86.

11. Rice DH. Diagnostic imaging. In: Cummings CW, Fredrickson JM, Harker LA, Krause CJ, Schuller DE, Eds. Otolaryngology: Head and neck surgery, 1st ed. St Louis, Missouri, USA: Mosby, 1986. Pp. 987-98. 